\title{
SYSTEM IDENTYFIKACJI WIZUALNEJ JAKO ELEMENT TOŻSAMOŚCI BIBLIOTEKI AKADEMICKIEJ
}

\begin{abstract}
The article presents the problem of creating and managing the brand of an academic library in the context of the university's identification system. Visual identity, understood as a mosaic of all visual messages, which facilitates recognition of a public institution, as well as brand awareness and development of long-term marketing strategies are the basic issues related to visual identification. The brand book (identity book), as well as printed and electronic materials, serve as a tool used to reinforce the institution's position on the market, and generate a coherent and logical system of symbols and connotations. The creation of a strong logo is one of the most important stages of building a corporate image, which has an ongoing influence on recipients and contributes to the success of a university and academic library brand.
\end{abstract}

Słowa kluczowe: identyfikacja wizualna, biblioteka akademicka, system identyfikacji wizualnej, tożsamość biblioteki akademickiej

Biblioteki szkół wyższych, podobnie jak wszelkie podmioty podlegające prawom rynku, wymagają długofalowej strategii marketingowej koniecznej dla zaznaczenia swojej obecności i wyróżnienia się spośród innych instytucji pełniących podobną rolę. Działanie biblioteki akademickiej podlega podobnym uwarunkowaniom istnienia w kulturze wizualnej współczesnego świata, jak innych instytucji biznesowych. Panowanie kultury obrazu nad kulturą słowa, znaczenie obrazu w komunikacji międzyludzkiej, zanurzenie się w ikonosferze to komponenty otaczającej nas kultury audiowizualnej. Ikoniczność staje się formą komunikacji wyróżniającej się swoją skutecznością, otaczającą nas zewsząd nieustannie, w sposób ciągły i dominujący. Jest to komunikacja jednostronna, pozbawiona interakcji, często wymuszona przez środki masowego przekazu. Źródłem jej jest telewizja, radio, Internet, prasa, ale przede wszystkim wszechobecna reklama wypełniona obrazami i dźwiękami. W rezultacie obrazy i słowa rywalizują ze sobą, lecz w tej rywalizacji wygrywa obraz. „Inwazja obrazu odpowiada na potrzebę dwojakiej - poznawczej i emocjonalnej natury. Na płaszczyźnie emocjonalnej obraz, bezpośrednio interpretowany 
przez układ limbiczny najstarszej części naszego mózgu, czaruje nas i przemawia do serca, tworząc wrażenia, zanim zdołamy je poddać analizie logicznej"1. Ikony pomagają nam poruszać się we współczesnym świecie, organizują ruch uliczny, pokazują drogę, informują na dworcach, autostradach, lotniskach. Zapraszają do hipermarketów i muzeów. Współczesny użytkownik czasem częściej posługuje się obrazem niż słowem pisanym, a na pewno silniej reaguje na obraz - sugestywny, wywołujący natychmiastowe emocje, łatwy w odbiorze, wszechobecny.

W takich okolicznościach trudniej przebić się jednostce mniej agresywnej lub dysponującej niewielkimi funduszami, posiadającej produkt atrakcyjny dla nielicznej grupy odbiorców. Tym większy należy położyć nacisk na jakość strategii marketingowej, odpowiednio dobrane narzędzia, konsekwencję i spójność stosowanej promocji biblioteki akademickiej. Istotna jest również zgodność z misją uczelni przy której biblioteka funkcjonuje. Błędy popełnione w fazie wstępnej, zbytni pośpiech, niekonsekwencje, brak wewnętrznej spójności mogą wpłynąć na niepowodzenie polityki tworzenia wizerunku biblioteki. Jak podają Bernd Schmitt i Alex Simonson ,jednym z podstawowych celów zarządzania tożsamością przez estetykę jest doprowadzenie do tego, aby organizacja i jej marki były zawsze kojarzone z właściwym dla nich stylem"2. Pierwsze skojarzenia odbiorcy to jednocześnie elementy charakterystyczne dla wizerunku graficznego firmy: logo, kolorystyka, oznakowanie wewnętrzne i zewnętrzne. Odpowiednio dobrane, dopracowane i konsekwentne pozostają w pamięci użytkownika oraz tworzą wizerunek firmy.

Celem nadrzędnym stosowania w bibliotece systemu identyfikacji wizualnej jest oczywiście tworzenie właściwego systemu skojarzeń potencjalnego czytelnika z konkretną placówką biblioteczną. Jeżeli w umyśle użytkownika zbudujemy ciąg pozytywnych asocjacji z naszą biblioteką dalszym zadaniem stanie się utrzymanie jego zainteresowania poprzez budowanie głębokiej więzi $\mathrm{z}$ instytucją, traktowaną jako godna zaufania, profesjonalna i nowoczesna.

Kluczem do budowania właściwej relacji z otoczeniem jest właściwy dobór komponentów identyfikacji wizualnej. Za podstawowe składniki tego systemu uważa się: nazwę biblioteki, logo (znak) firmy, ekslibris, stronę internetową, kolorystykę, typografię, wystrój wnętrz, zewnętrzną aranżację firmy,

\footnotetext{
${ }^{1}$ Ch. Vandendorpe, Od papirusu do hipertekstu: esej o przemianach tekstu i lektury, Warszawa 2008, s. 137.

${ }^{2}$ B. Schmitt, A. Simonson, Estetyka $w$ marketingu: strategiczne zarzadzanie markami, tożsamością i wizerunkiem firmy, Kraków 1999, s. 128.
} 
materiały reklamowe, druki firmowe, używane symbole i skróty, ubiór pracowników, identyfikatory, tablice informacyjne, a także flagi, transparenty czy banery, maskotki, upominki i inne ${ }^{3}$. Do tej listy można też dodać spójność polityki wizualizacji biblioteki akademickiej z polityką uczelni wyższej.

\section{Biblioteka Politechniki Lubelskiej}
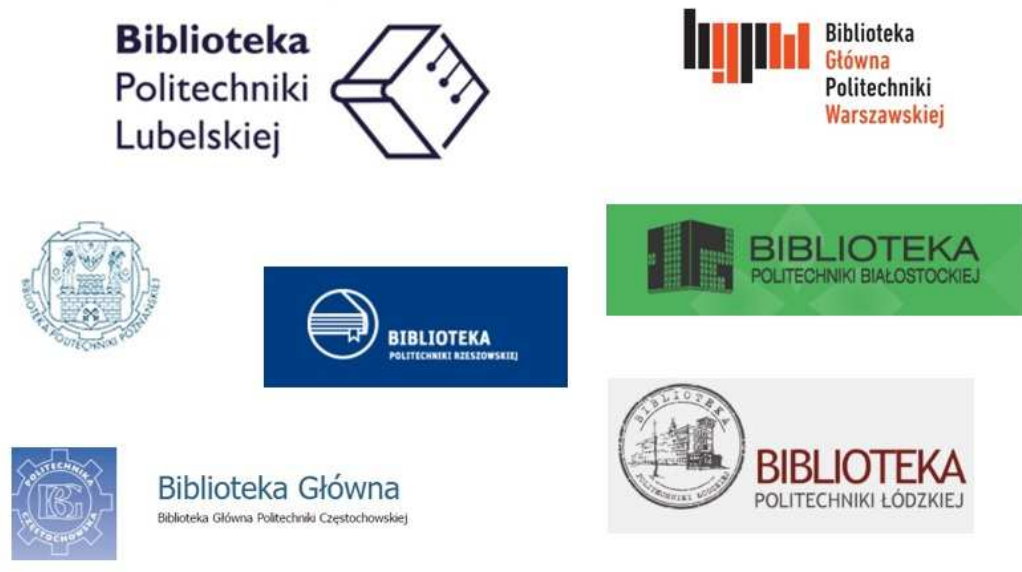

Biblioteka Główna

Biblioteka Growna Poltectnio Czestochowskej

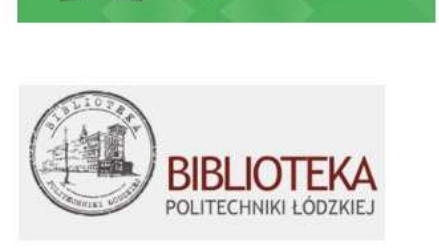

Rys. 1. Przykłady istniejących logotypów bibliotek polskich politechnik

Źródło: Biblioteka Politechniki Lubelskiej, http://biblioteka.pollub.pl/, [dostęp: 10.10. 2017]; Biblioteka Główna Politechniki Warszawskiej, http://www.bg.pw.edu.pl/, [dostęp: 10.10.2017]; Biblioteka Politechniki Krakowskiej, https://www.biblos.pk.edu.pl/, [dostęp: 10. 10.2017]; Biblioteka Politechniki Rzeszowskiej, http://biblio.prz.edu.pl/, [dostęp: 10.10.2017]; Biblioteka Politechniki Białostockiej, http://biblioteka.pb.edu.pl/, [dostęp 10.10.2017]; Biblioteka Główna Politechniki Częstochowskiej, http://www.bg.pcz.pl/, [dostęp 10.10.2017]; Biblioteka Główna Politechniki Łódzkiej, http://bg.p.lodz.pl/, [dostęp 10.10.2017].

${ }^{3}$ Podstawowe składniki systemu identyfikacji wizualnej podaje: M. Jurowski w artykule Jednolita identyfikacja wizualna, Biuletyn EBIB nr 5/2004, http://www.ebib.pl/?page_id=24, [dostęp: 25.09.2017]; R. Augustyn i U. Kawecka w artykule System identyfikacji wizualnej biblioteki jako element komunikacji z czytelnikiem, „Biuletyn EBIB” 2011, nr 5, http:// www.ebib.pl/?page_id=24, [dostęp: 25.09.2017]; M. Wojciechowska w artykule Fizyczne artefakty kultury organizacyjnej jako element komunikacji marketingowej: na przykładzie systemu komunikacji wizualnej, http://docplayer.pl/16268985-Fizyczne-artefakty-kultury-organizacyjnejjako-element-komunikacji-marketingowej-na-przykladzie-systemu-identyfikacji-wizualnej.html, [dostęp: 25.09.2017]; P. Bajbak w artykule Struktura systemu identyfikacji wizualnej firmy, [w:] Produkcja przekazów multimedialnych, red. M. Chrząścik, Warszawa 2013, a także wiele ogólnodostępnych stron internetowych między innymi: Poradnik Przedsiębiorcy, https:// poradnikprzedsiebiorcy.pl/, [dostęp: 10.10.2017]; Wizualni, https://wizualni.pl/, [dostęp: 10.10. 2017]; Brandoxygen, http://brandoxygen.pl/, [dostęp: 10.10.2017]; 6 Kroków, https://6kr okow.pl/stworz-spojny-system-identyfikacji-wizualnej-firmy/ i temu podobnych, [dostęp: 10.10. 2017]. 
Pracownicy biblioteki, tworzący strategię marketingową swojej placówki stają przed zadaniem nie tylko dotyczącym sfery wizualnej czy też graficznej, ale przede wszystkim muszą zidentyfikować właściwe cele planowanych zadań. Identyfikacja odbiorców przekazu, czas trwania akcji (jednorazowa, czy długotrwała), dobór treści i sposobu komunikacji z klientem, wydzielenie konkretnych środków finansowych, wreszcie zaplanowanie taktyki zbadania efektów strategii to podstawowe składniki powodzenia opracowania właściwej strategii marketingowej. Procedury komunikacji marketingowej wdrażanej przez biblioteki oznaczają dążenie do stanu zgodności między postrzeganiem biblioteki przez otoczenie, a postrzeganiem biblioteki przez samą siebie. Celem ostatecznym jest uzyskanie jednolitego i spójnego wizerunku firmy, wyróżniającego się na tle innych, podobnych placówek naukowych, stwarzającego w umyśle odbiorcy wrażenie zarazem profesjonale i przyjazne. Jak podaje Zbigniew Bentyn „Budowa korzystnego wizerunku sprowadza się do wykreowania pozytywnych skojarzeń przejawów działalności przedsiębiorstwa wśród grupy docelowej. (...) Może nim być wizja przedsiębiorstwa, jego misja lub szczególny sposób działania. Przedsiębiorstwa chcące się wyróżnić z szeregu podobnych kładą szczególny nacisk na wplecenie w swój organizacyjny porządek idei bliskich otoczeniu przedsiębiorstwa. Otoczeniu rozumianemu jako grupy pracowników, klientów, i szeroko rozumianej opinii publicznej”4 . Istotnym staje się podjęcie próby zaangażowania emocjonalnego odbiorców poprzez związanie ich $\mathrm{z}$ marką biblioteki. Funkcjonowanie bibliotek, w szczególności bibliotek akademickich, opiera się na stałości i ciągłości, a cel istnienia bibliotek nie ulega zmianie $\mathrm{z}$ biegiem czasu. Modyfikacjom mogą ulec formy działalności, mogą pojawić się cele krótkotrwałe, środek ciężkości aktywności placówki może przesuwać się na osi czasu, lecz cel długotrwały funkcjonowania biblioteki to kontynuacja i systematyczność w pozyskiwaniu nowych klientów-użytkowników i utrzymanie zainteresowania czytelników już pozyskanych. Celem nadrzędnym i niezmiennym akcji promocyjnej biblioteki jest $\mathrm{w}$ istocie rzeczy pewna powtarzalność przekazywanych komunikatów i utrwalanie ich w pamięci odbiorców. W rezultacie w pamięci adresatów naszego przekazu powinna się umocować informacja niosąca przekaz związany z biblioteką jako miejscem reprezentującym stałość, niezmienną wartość i walor nie podlegający zmiennym fluktuacjom. Taki obraz biblioteki powstaje latami, początkowo jedynie wśród społeczności akademickiej, jednakże z czasem przedostaje się do świadomości szerszej publiczności, mediów i ogółu społeczeństwa.

\footnotetext{
${ }^{4}$ Z. Bentyn, Identyfikacja wizualna przedsiębiorstwa, Poznań 2011, s. 15.
} 
Nie bez znaczenia pozostaje ochrona tak utworzonej wartości poprzez utrzymanie wysokiego poziomu jakości, aktualności i koherentności.

Tożsamość instytucji kulturalnej należy postrzegać jako taki zestaw jej działań i cech, który pozwala odróżnić daną instytucję od innej, szczególnie oferującej podobny zakres usług. „Oczywista jest więc współzależność pomiędzy pojęciami wizerunek i tożsamość, ponieważ na to, co ludzie pomyślą o firmie, ma również wpływ przyjęty przez nią sposób prezentacji (system identyfikacji). Podstawowa różnica między tymi pojęciami polega na tym, że wizerunek jest czymś zewnętrznym wobec firmy, czymś na co firma może jedynie starać się wpłynąć i kształtować według potrzeb. Tożsamość zaś stanowi nieodłączny element firmy, o którym może ona w pełni decydować"5.

Alternatywą dla książki są nowe media i nowe sposoby uzyskiwania informacji. Ustawiczny natłok informacji, szum informacyjny, mnogość przekazów docierających w każdej chwili do współczesnego odbiorcy, potok ofert, komunikatów, zawiadomień, reklam tworzy chaos informacyjny, który trudno opanować i któremu trudno się oprzeć. Nadmiar informacji, szczególnie wizualnej, nie pozwala skupić się i odetchnąć nawet na chwilę. Potrzeba bycia nieustannie informowanym na bieżąco, niemożność odcięcia się od napływającej informacji charakteryzuje w dużym stopniu współczesnego odbiorcę. Nadprodukcja informacji nie zostawia czasu na wybór między wiadomościami istotnymi i mniej istotnymi, między sprawami ważnymi a spamem. W rezultacie informacje istotne gubią się między mniej istotnymi, a co więcej pośpiech w którym żyjemy nie pozwala ich odróżnić ${ }^{\text {. }}$

Tym istotniejsze staje się budowanie tożsamości wizerunkowej instytucji, która pragnie przebić się na rynku kulturalnym. Biblioteka akademicka, która musi konkurować z bogatą ofertą mediów produkujących w każdej sekundzie potok informacji zalewających czytelników, wyświetlających się w Internecie, na ekranie komputera, tabletu, komórki, telewizora stawia sobie trudne zadanie przebicia się ze swoją misją do świadomości czytelnika. Bibliotekarz nie jest już głównym pośrednikiem w przekazywaniu wiedzy o świecie, czytelnictwo spada, a użytkownicy nierzadko poprzestają na krótkich wiadomościach przesyłanych lawinowo przez portale internetowe. Biblioteka akademicka nie posiada tak atrakcyjnych możliwości technicznych jak współczesne media, jednakże nie może pozwolić na zmarginalizowanie swojej oferty. Stoją za nią

\footnotetext{
${ }^{5}$ A. Kwiecień, Przestanki i czynniki ksztaltowania reputacji firmy, „Ekonomia” 2003, nr 10, s. 140.

${ }^{6}$ Szerzej tematyka ekologii informacji jest omawiana w publikacjach: W. Babik, Ekologia informacji, Kraków 2014; Ekologia informacji a kultura informacyjna społeczeństwa, red. B. Taraszkiewicz, Słupsk 2016; Ekologia informacji w e-spoteczeństwie, red. B. Taraszkiewicz, Słupsk 2014.
} 


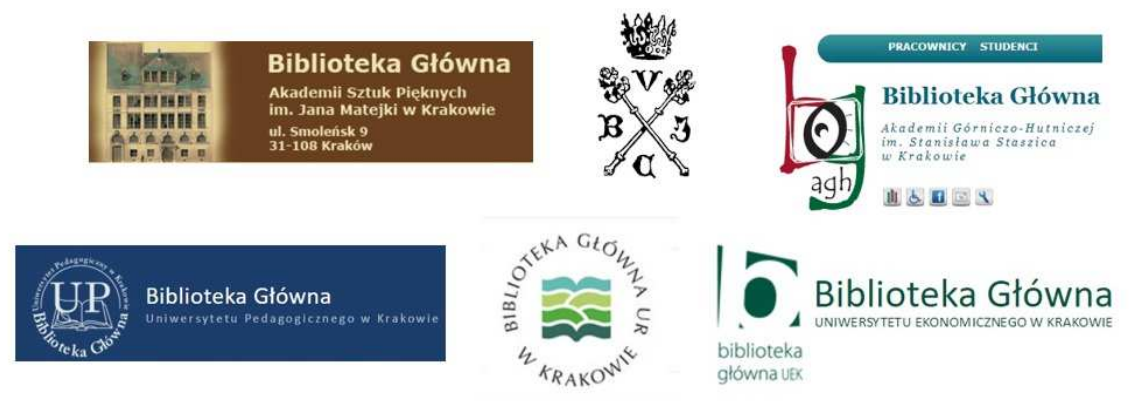

Rys. 2. Przykłady logotypów krakowskich bibliotek szkół wyższych.

Źródło: Strony internetowe Biblioteki Głównej Akademii Sztuk Pięknych w Krakowie, http://bg.asp.krakow.pl/bg/, [dostęp: 10.10.2017]; Biblioteki Jagiellońskiej Uniwersytetu Jagiellońskiego, http://www.bj.uj.edu.pl/, [dostęp: 10.10.2017]; Biblioteki Głównej Akademii Górniczo-Hutniczej, http://www.bg.agh.edu.pl/, [dostęp: 10.10.2017]; Biblioteki Głównej Uniwersytetu Pedagogicznego w Krakowie, http://bg.up.krakow.pl/, [dostęp: 10.10.2017]; Biblioteki Głównej UR w Krakowie, http://biblioteka.ur.krakow.pl/, [dostęp: 10.10.2017]; Biblioteki Głównej Uniwersytetu Ekonomicznego w Krakowie, http://kangur.uek.krakow.pl/, [dostęp: 10.10.2017].

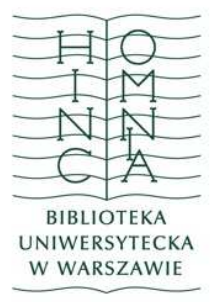

\section{Q) Biblioteka Uniwersytetu Gdańskiego}
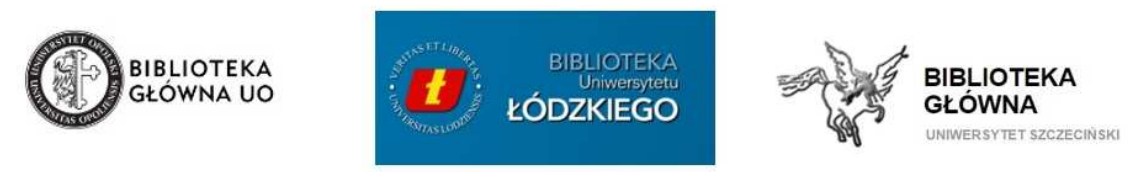

Rys. 3. Przykłady stosowania logotypów polskich bibliotek uniwersyteckich.

Źródło: strony internetowe: Biblioteki Uniwersyteckiej w Warszawie, http://www.buw. uw.edu.pl/, [dostęp: 10.10.2017]; Biblioteki Uniwersytetu Gdańskiego, http://www.bg.ug.edu. pl/, [dostęp: 10.10.2017]; Biblioteki Uniwersyteckiej im. Jerzego Giedroycia w Białymstoku, http://bg.uwb.edu.pl/, [dostęp: 10.10.2017]; Biblioteki Głównej Uniwersytetu Opolskiego, http:// bg.uni.opole.pl/, [dostęp: 10.10.2017]; Biblioteki Uniwersytetu Łódzkiego, http://www.lib. uni.lodz.pl/, [dostęp: 10.10.2017]; Biblioteki Głównej Uniwersytetu Szczecińskiego, https:// bg.szczecin.pl/, [dostęp: 10.10.2017]. 
wartości pozaczasowe, wiedza sprawdzona, najwyższej jakości, uporządkowana i usystematyzowana. Biblioteki akademickie dysponują najczęściej doskonałą infrastrukturą, wykwalifikowaną kadrą, życzliwym personelem. Pozostaje więc tylko przebić się ze swoją ofertą do świadomości środowiska akademickiego.

Powody rozpoczęcia pracy nad budową tożsamości wizualnej biblioteki mogą być różnorakie, począwszy od najbardziej oczywistych, to jest od potrzeby poinformowania potencjalnych użytkowników o naszym istnieniu lub zareklamowanie nowej usługi wśród dotychczasowych i ewentualnych czytelników. Poszukiwanie nowych form wyrazu reklamujących instytucję może też wynikać z chęci ściągnięcia publiczności na organizowane wydarzenie, pokaz, wystawę, warsztaty czy zabawy. Budowanie pozytywnej marki biblioteki, utrwalenie osiągnięć i stworzenie koncepcji na przyszłość to podstawowe zadania osób zajmujących się wizerunkiem instytucji.

Tożsamość wizualna rozumiana jako system jednorodnych komunikatów opiera się na identyfikacji wizualnej tworzącej homogeniczny zbiór symboliki stosowanej przez instytucję. Komunikat wizualny przekazywany odbiorcy za pośrednictwem wzroku opiera się na obrazie, tworząc wzór pozytywnych skojarzeń staje się silnym narzędziem promocyjnym ${ }^{7}$. Jego podstawowym celem jest zwrócenie i utrzymanie uwagi, wywołanie zainteresowania, nakłonienie do skorzystania z oferty, wreszcie zatrzymanie użytkownika na stałe. Potrzeba odróżnienia od innej podobnej instytucji, a także konkurencja $\mathrm{z}$ wszechobecnym Internetem oznacza konieczność planowania strategii marketingowej na dłuższy czas, a także zgodę na pracę systematyczną, ciągłą i wymagającą cierpliwości. Tym bardziej istotne są wstępne założenia strategii budowy tożsamości wizualnej biblioteki, bowiem od wstępnych założeń, a potem od ich konsekwentnego stosowania może zależeć powodzenie akcji.

Identyfikacja wizualna firmy powinna odpowiadać specyfice konkretnej biblioteki, a w przypadku biblioteki akademickiej być spójna z wizją identyfikacji całej uczelni. Można wymienić podstawowe cechy prawidłowej identyfikacji wizualnej:

- jednolitość i zgodność;

- $\quad$ oryginalność i indywidualność;

- czytelność i przejrzystość;

- $\quad$ łatwość skojarzenia i zapamiętania;

- $\quad$ konsekwencja, logika i spójność;

${ }^{7}$ A. Kmita, Identyfikacja firmy: system komunikatów wizualnych, Sosnowiec 2006, s. 11. 
- prostota i ekonomiczność;

- $\quad$ łatwość transformacji i odnawiania wizerunku;

- powinna posiadać skojarzenia $\mathrm{z}$ daną instytucją ${ }^{8}$.
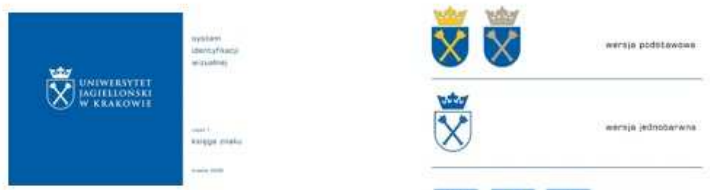

圆圆圆一
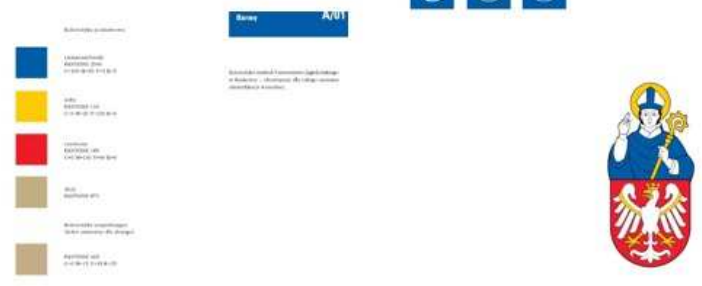
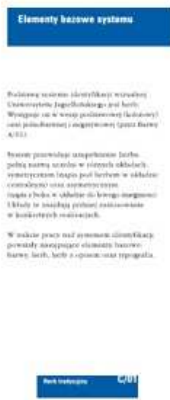

Rys. 4. Przykład struktury Księgi Znaku (fragment):

Księga Znaku Uniwersytetu Jagiellońskiego w Krakowie

Źródło: Dział Promocji Uniwersytetu Jagiellońskiego w Krakowie, http://www.promocja. uj.edu.pl/system-identyfikacji-wizualnej, [dostęp: 11.12.2017].

Dla zilustrowania typowych logotypów polskich bibliotek szkół akademickich wybrano przykłady ze stron internetowych instytucji grupując je według rodzajów uczelni (rys. 1-3): biblioteki politechnik, biblioteki krakowskich szkół wyższych, biblioteki uniwersyteckie). Wszystkie z wybranych logotypów charakteryzują się różnorodnością w formie pozwalającej na ich łatwe powiązanie z konkretną biblioteką. Kolorystyka stosowana w oznaczeniach logotypów nie jest jednolita, przeciwnie, wśród ilustracji można znaleźć przykłady zastosowania pełnej gamy kolorów, jakkolwiek przeważają barwy stonowane, na przykład niebieski, zielony i brązowy. Większość logotypów związanych jest tematycznie z instytucją, którą reprezentują, szczególnie wśród wizualizacji bibliotek politechnik: wśród rysunków można zidentyfikować symbole kojarzące się z techniką, mechaniką czy elektroniką. Częstym motywem znajdowanym na logotypie jest przedstawienie budynku konkretnej

${ }^{8} \mathrm{Na}$ podstawie: Z. Bentyn, Identyfikacja wizualna przedsiębiorstwa, Poznań 2011; K.J. Rychter, Z. Chmielewski, D. Tworzydło, Tożsamość wizualna: znak, system wizerunek, Rzeszów 2012; Oblicza komunikowania wizualnego, red. R. Polaka, Kraków-Rzeszów-Zamość 2011. 
biblioteki, takie przedstawienie znajdujemy między innymi na logotypach Biblioteki Politechniki Łódzkiej', Biblioteki Politechniki Białostockiej czy Biblioteki Akademii Sztuk Pięknych w Krakowie, a również na logotypie Biblioteki Uniwersytetu Gdańskiego widzimy wyobrażony fragment charakterystycznej elewacji budynku biblioteki, jakkolwiek jest on rozpoznawalny tylko dla osób, które ten budynek znają. Następnym elementem powtarzającym się są symbole związane $\mathrm{w}$ sposób oczywisty $\mathrm{z}$ biblioteką, a więc książka w różnych formach: najczęściej otwarta - na przykład w logotypach Biblioteki Uniwersytetu Warszawskiego, Biblioteki Uniwersytetu Pedagogicznego w Krakowie czy Biblioteki Uniwersytetu Rolniczego w Krakowie; książka zamknięta, ale z widoczną zakładką (Biblioteka Uniwersytetu Pedagogicznego w Krakowie), lub książki ustawione w formie regału (Biblioteka Politechniki Warszawskiej); dodatkowo na logotypie Biblioteki Politechniki Łódzkiej znajdujemy stylizowaną pieczęć biblioteczną. Biblioteki, które bardziej pragną być kojarzone z miastem, w którym się znajdują, reprezentują na swoich logotypach herby miejscowości (Biblioteka Politechniki Poznańskiej, Biblioteka Uniwersytetu Opolskiego, Biblioteka Uniwersytetu Łódzkiego) - jednakże we wszystkich wymienionych przypadkach logotyp biblioteki głównej jest tożsamy z logotypem właściwej uczelni. Ciekawej zmianie w ostatnich dniach uległy logotypy Uniwersytetu Łódzkiego i Biblioteki Uniwersytetu Łódzkiego, które nie przedstawiają już stylizowanej litery „Ł” koloru żółtego na tle tarczy herbowej w kolorze czerwonym (rys. 3), lecz stylizowaną literę „U” wraz ze strzałką skierowaną w górę - Biblioteka Uniwersytetu Łódzkiego - znak biały na niebieskim tle, Uniwersytet Łódzki - znak czerwony na białym tle (rys. 5). Wśród grafik oznaczających biblioteki szkół wyższych można dostrzec także stylizowane inicjały instytucji: litery „BG” (Biblioteka Główna Akademii Górniczo-Hutniczej w Krakowie), literę „B” (Biblioteka Główna Uniwersytetu Ekonomicznego w Krakowie), litery „BU” (Biblioteka Uniwersytecka im. Jerzego Giedroycia w Białymstoku). Na podobnej zasadzie oznaczania instytucji opiera się logotyp Biblioteki Jagiellońskiej w Krakowie stanowiący nawiązanie do historycznej pieczęci bibliotecznej (litery B oraz UJC oznaczające Universitas Jagellonica Cracoviensis wraz ze skrzyżowanymi berłami oraz koroną). Omówione powyżej logotypy, nazywane przez Tomasza Kruszewskiego konwencjonalnymi ${ }^{10}$, można ocenić jako czytelnie wskazujące daną bibliotekę,

\footnotetext{
${ }^{9}$ Biblioteka Politechniki Łódzkiej w ostatnich dniach zmieniła swój logotyp, który przybrał formę prostszą, a przez co bardziej nowoczesną, niemniej jednak na logotypie znajdujemy w dalszym ciągu stylizowany budynek biblioteki.

${ }^{10}$ T. Kruszewski, Przestrzenie biblioteki, Torun 2012, s. 80.
} 
realistyczne (brak wśród nich grafik abstrakcyjnych), mocno związane z instytucją, którą reprezentują. Jak pisze Krzysztof Albin „określona całość tekstowa przekazuje informację, która z punktu widzenia nadawcy ma charakter skończony. Tekst ma zatem funkcję wyjaśniającą i jako całość powinien skutecznie znosić niepewność odbiorcy, gdy idzie o jego treść"11.
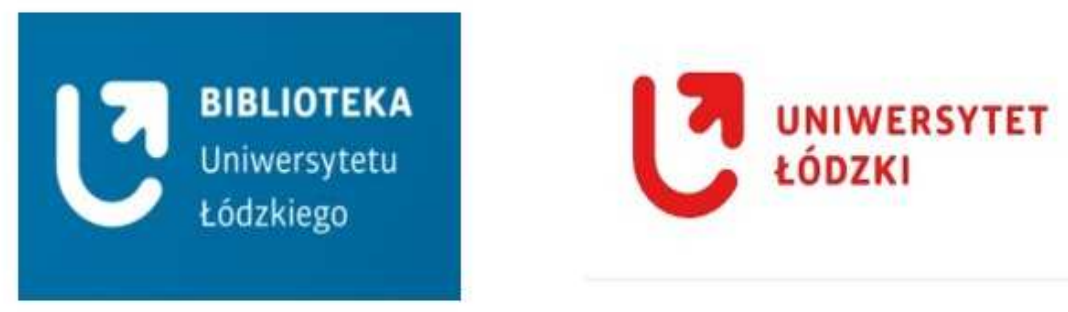

Rys. 5. Nowe logotypy Biblioteki Uniwersytetu Łódzkiego i Uniwersytetu Łódzkiego 2017].

Źródło: Biblioteka Uniwersytetu Łódzkiego, http://www.lib.uni.lodz.pl/, [dostęp: 10.10.

Liczba komunikatów, jakie niesie ze sobą cały system komunikacji społecznej organizacji i stopień złożoności całego systemu zależy od wielu czynników, między innymi od stopnia złożoności samej instytucji, jej schematu organizacyjnego, charakteru firmy, wreszcie od potrzeb dla których jest projektowany system identyfikacji. Komunikat powinien nieść ze sobą jednoznaczną treść, która złoży się na spójny i efektywny obraz instytucji oddający zarazem zamierzenia twórców systemu tożsamości.

Graficzną formą komunikatu wizualnego jest $\log 0^{12}$ przedstawiające symbol i nazwę organizacji. Terminu logo używamy dla całego unikalnego znaku, składającego się, na ogół, z sygnetu (symbolu graficznego) i logotypu (tekstowego przedstawienia nazwy). Dodatkowym elementem występującym w logo, coraz chętniej wprowadzanym szczególnie w przedsiębiorstwach typu komercyjnego, jest hasło firmowe.

\footnotetext{
${ }^{11}$ K. Albin, Reklama. Przekaz, odbiór, interpretacja, Warszawa 2000, s. 73.

${ }^{12} \mathrm{Na}$ potrzeby tego artykułu przyjęto następującą definicję terminu logo: „logotyp (znak towarowy, logomark) to nazwa firmy (lub jej skrót) zapisana charakterystycznym krojem pisma i przy użyciu firmowych kolorów, często poszerzona o znak firmowy. Dzięki dodatkom graficznym i niebanalnej formie ułatwia zapamiętanie nazwy obiektu, do którego się odnosi”, za: A. Benicewicz-Miazga, Grafika w biznesie, Gliwice 2005, s. 109.
} 


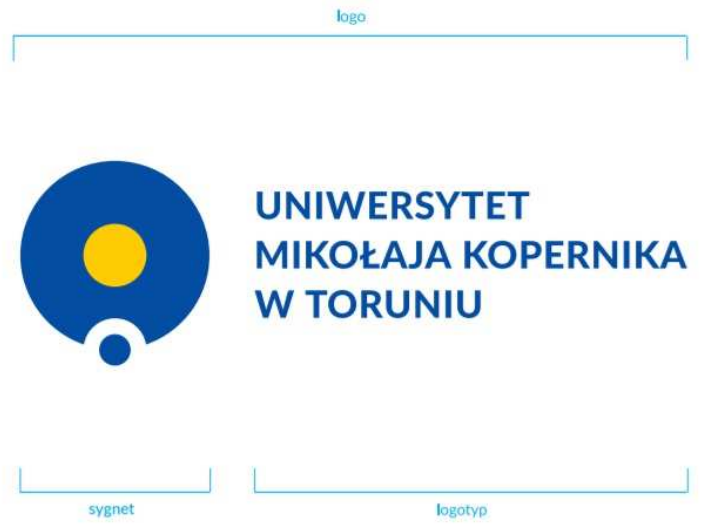

Rys. 6. Przykład struktury prawidłowego logo: logo Uniwersytetu Mikołaja Kopernika w Toruniu 10.2017].

Źródło: Uniwersytet Mikołaja Kopernika w Toruniu, https://www.umk.pl/, [dostęp: 10.

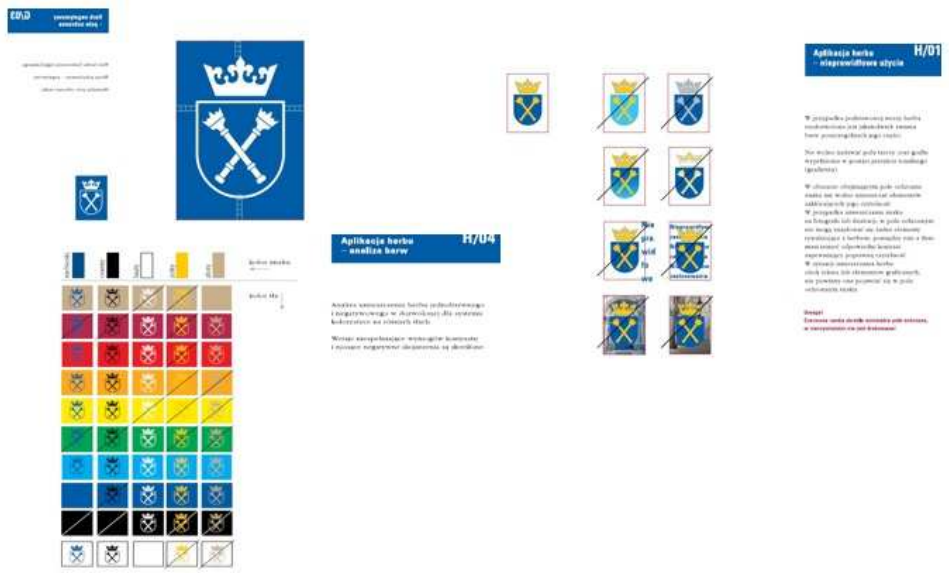

Rys. 7. Przykład struktury Księgi Znaku (fragment):

Księga Znaku Uniwersytetu Jagiellońskiego w Krakowie

Źródło: Dział Promocji Uniwersytetu Jagiellońskiego w Krakowie, http://www.promocja. uj.edu.pl/documents/1417014/109833152/ksiega_znaku_2009.pdf/ad69b5d6-1ff9-49f4-bf5b-f61 76492013a, [dostęp: 10.10.2017].

Na znak jako na nośnik informacji ma wpływ wiele elementów: kompozycja, czytelność, symetria, kształt, proporcja, kolor, typografia. Może wywodzić się z historii instytucji i nieść skojarzenia z jej przeszłością lub odnosić się do nowoczesności i dynamiki współczesnej instytucji akademickiej. Tworzy więź między nadawcą a odbiorcą, a o jego sile świadczy waga z jaką 
pracownicy identyfikują się z firmą. Znak tożsamości instytucji jest również rozpoznawalny dla klientów i powinien również dla nich nieść pozytywne skojarzenia. Stworzenie silnego i atrakcyjnego znaku jest jednym z najważniejszych etapów budowania wizerunku organizacji $1^{13}$.

Z powodów praktycznych należy tak zaplanować znak (logo) biblioteki, aby możliwe było tworzenie na bieżąco jego odmian możliwych do zamieszczenia na różnych nośnikach i w różnej skali bez strat jakości. Znak biblioteki powinien być równie czytelny na dużym banerze czy plakacie, jak i na maskotce firmowej lub wizytówce. Powinien się dobrze prezentować na stronie internetowej (właściwa rozdzielczość) oraz wydrukowany w technice sitodruku lub na offsecie. Tematyka znaku biblioteki może dotyczyć samej specyfiki instytucji, a więc przedmiotu czy też przedmiotów kojarzonych dosłownie, na przykład z książką lub budynkiem biblioteki lub może stanowić tylko wyobrażenie graficzne obiektu, albo kompozycję abstrakcyjną. Warunkiem podstawowym w doborze znaku jest uznanie go za równie zrozumiały dla nadawców i odbiorców. Współczesna grafika użytkowa stara się raczej wyrazić ideę, misję czy przesłanie organizacji przenosząc akcent z funkcji czysto informacyjnej na budowanie emocjonalnych relacji z odbiorcą.

Na system identyfikacji wizualnej biblioteki składają się:

- $\quad$ symbol (znak i logotyp firmowy);

- $\quad$ typografia i barwy znaku;

- druki firmowe (papier, koperty, dokumenty i inne);

- identyfikatory i ubiór pracowników;

- $\quad$ pieczątki, drobne gadżety, maskotki, karty świąteczne i temu podobne;

- materiały reklamowe w każdej postaci;

- materiały drukowane dla celów public relations;

- $\quad$ środki transportu (samochody ciężarowe, osobowe);

- $\quad$ wystrój stoisk, lad bibliotecznych, okienek w informatorium;

- $\quad$ aranżacja wnętrz siedziby oraz wygląd otoczenia;

- $\quad$ tablice i tabliczki informacyjne, szyldy reklamowe;

- $\quad$ banery, plakaty, prezentacje power point, stopki w poczcie elektronicznej;

- $\quad$ akcydensy (druki o charakterze użytkowym - katalogi, naklejki, etykiety, barkody);

- $\quad$ exlibrisy i znaki wodne.

${ }^{13}$ M. Kaczmarczyk, Public relations szkót wyższych: model komunikowania się z otoczeniem w demokratycznej przestrzeni publicznej, Sosnowiec 2013, s. 511. 


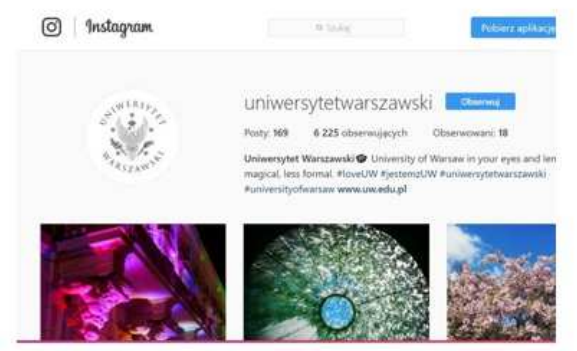

Linked in
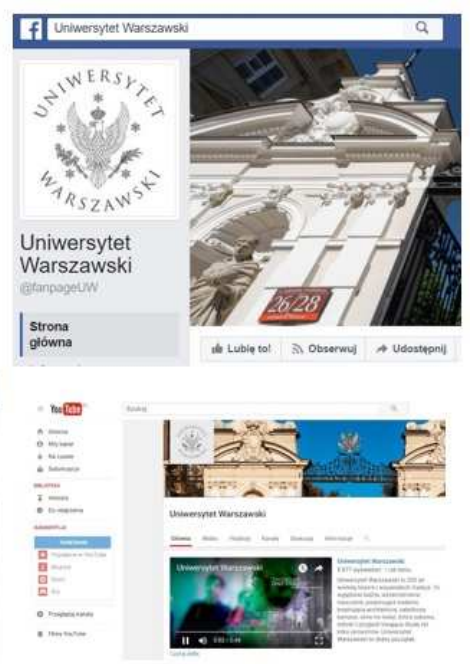

Rys. 8. Przykład stosowania jednolitego oznakowania instytucji w różnych mediach internetowych: Instagram, Facebook, LinkedIn, YouTube: Uniwersytet Warszawski.

Źródło: Strony na portalach społecznościowych Uniwersytetu Warszawskiego: Instagram, ihttps://www.instagram.com/uniwersytetwarszawski/, [dostęp: 10.10.2017]; Facebook, https:// www.facebook.com/fanpageUW, [dostęp: 10.10.2017]; Linkedin, https://www.linkedin.com/ edu/schoolid=16009\&trk=tyah\&trkInfo=clickedVerticalschoolclickedEntityId 16009idx3-1-7tar Id1455183114417tasuniwersytet, [dostęp: 10.10.2017], YouTube, https://www.youtube.com/ user/UWpromocja, [dostęp: 10.10.2017].
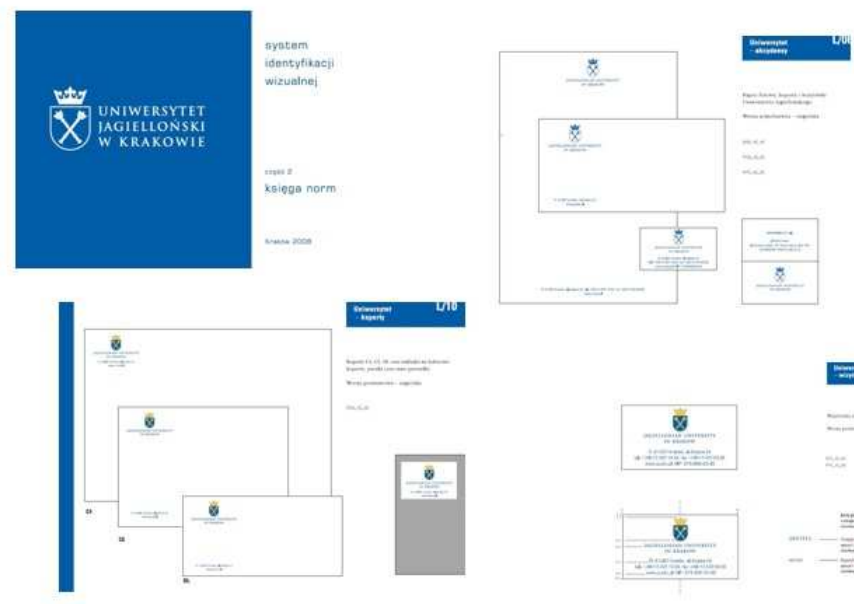

Rys. 9. Przykład struktury Księgi Znaku (fragment):

Księga Znaku Uniwersytetu Jagiellońskiego w Krakowie

Źródło: Dział Promocji Uniwersytetu Jagiellońskiego w Krakowie, http://www.promocja. uj.edu.pl/documents/1417014/109833152/ksiega_znaku_2009.pdf/ad69b5d6-1ff9-49f4-bf5b-f61 76492013a, [dostęp: 10.10.2017]. 
Jako przykład rozbudowanej i uwzględniającej wszelkie konieczne aspekty budowy tożsamości instytucji akademickiej może służyć System identyfikacji wizualnej Uniwersytetu Warszawskiego ${ }^{14}$. System identyfikacji wizualnej został wprowadzony Zarządzeniem Rektora z dnia 2 stycznia 2017 r. i składa się z Księgi znaku zawierającej szczegółowy opis znaku UW, oraz z Księgi identyfikacji wizualnej zawierającej opis typografii, kolorystyki oraz poszczególnych elementów systemu identyfikacji wizualnej ${ }^{15}$. Księga znaku omawia w sposób szczegółowy logo Uniwersytetu: logo podstawowe i uzupełniające, logo monochromatyczne i kolorowe, odmiany logo rektorskiego, uwzględniając również tłoczenia, grawerowanie oraz tak zwane praktyki zakazane; a także symbole Uniwersytetu: godło, pieczęć, sztandar. Księga identyfikacji wizualnej podaje obowiązująca paletę kolorystyczną, typografię (zarówno w odniesieniu do druku, jak i mediów elektronicznych oraz Internetu), wzory wizytówek służbowych, papierów firmowych poszczególnych instytucji uniwersyteckich, kopert, zaproszeń, a także korespondencji elektronicznej (stopka e-mail), identyfikatorów, flag, banerów, oznakowania filmów, stron internetowych i mediów społecznościowych. Na stronie Działu Promocji UW znajduje się także link do zamówień materiałów promocyjnych, wizytówek, pieczątek i kalendarzy przeznaczony dla pracowników Uniwersytetu. Dodatkowo uczelnia oferuje bazę zdjęć oraz filmów o Uniwersytecie przeznaczoną na potrzeby wydziałów, jednostek i administracji. W sklepie internetowym można zapoznać się z bogatą ofertą gadżetów i książek o Uniwersytecie.

Chaos wizualny, jaki może spowodować nieprofesjonalne zastosowanie elementów nie współgrających ze sobą oraz niespójny przekaz poznawczy prowadzący do dezinformacji można opanować za pomocą księgi tożsamości wizualnej. Księga taka powinna być przygotowana w sposób profesjonalny, odzwierciedlać ducha instytucji, jej idee i cele, kojarzyć się pozytywnie, wzbudzić poczucie wspólnoty, podkreślić prestiż instytucji i jej konkurencyjność. Ponieważ elementy graficzne będą wielokrotnie powielane na zewnątrz budynków i w ich wnętrzach, utrwalą się w pamięci czytelników i będą przez nich rozpoznawane. Spójność i powtarzalność przekazu wizualnego będą budzić w odbiorcy zaufanie, poczucie wiarygodności i bezpieczeństwa. Księga tożsamości pozwala również uporządkować stosowane wcześniej symbole, jeżeli historia instytucji jest długa i biblioteka lub uczelnia posiada historyczny herb,

${ }^{14}$ Uniwersytet Warszawski, http://promocja.uw.edu.pl/siw-uw/ksiega-identyfikacji-wizu alnej/, [dostęp: 20.09.2017].

${ }^{15}$ Zarzadzenie nr 1 Rektora Uniwersytetu Warszawskiego z dnia 2 stycznia 2017 r. w sprawie wprowadzenia Systemu identyfikacji wizualnej Uniwersytetu Warszawskiego, [dostęp: 10.10.2017], http://monitor.uw.edu.pl/Lists/Uchway/Attachments/3958/M.2017.1.Zarz.1.pdf. 
pieczęć lub oznaczenie graficzne. W księdze tożsamości opisuje się szczegółowo znak organizacji opisując go na siatce, zakładając jeden moduł, którym można odmierzać wielkości wewnątrz znaku. Oprócz tego księga identyfikacji wizualnej firmy powinna zawierać wzór logotypu wraz z jego szablonami, numeryczne wartości dla barw zarówno do druku, jak i dla Internetu, szczegółowy opis typografii (kroje pisma), a także wersje elektroniczne każdego znaku. Dodatkowo należy opracować możliwości skalowania, odbić lustrzanych, wersji kolorowych i jednobarwnych, kontrastów kolorystycznych, pustego pola ochronnego wokół znaku i temu podobnych. Właściwie skonstruowana księga znaku nie pomija kwestii związanych z umieszczaniem logotypów na różnych tłach z wypełnieniem bądź bez wypełnienia, proporcji symboli, opisem krzywizn i kątów przecięcia się poszczególnych detali. Nie należy również zapominać o zakazie wprowadzania zmian, własnych przeobrażeń znaków i ich przekształcania.

Jak podają Krzysztof J. Rychter, Zbigniew Chmielewski i Dariusz Tworzydło znak firmowy oddziałuje na widza poprzez nazwę, grafikę, symboliczne i estetyczne skojarzenia i wrażenia oraz kompozycję. Nazwa - ma za zadanie wywołać skojarzenie i przynależność gramatyczną do rodzaju męskiego lub żeńskiego; graficzna forma logotypu - wskazuje na ogólny kształt, wzajemne usytuowanie elementów budujących znak firmowy, estetyczne wrażenia związane z figuratywną lub abstrakcyjną formą ikony; wreszcie barwy oraz rodzaj użytych liter budują symboliczne skojarzenia związane z ikoną (sygnetem) ${ }^{16}$.

Każdy z elementów systemu identyfikacji wizualnej ma charakter informacyjny, niosący ze sobą pewną wartość. Wybrany kolor (kolory) jest również metaforą związaną z historią, kulturą czy tradycją. Może posiadać znaczenie symboliczne, rozpoznawalne dla danej grupy odbiorców lub wywoływać pozytywne skojarzenia związane na przykład z czystą wodą, słońcem lub ogólnie zielenią. Określona barwa wybrana po starannej selekcji z palety odcieni może również służyć jako rozróżnienie w stosunku do logotypu innej, podobnej instytucji. Pozwoli to na łatwiejszą identyfikację naszego produktu, a także uzyskanie efektu zgodności z tożsamością naszej instytucji. Prawidłowo dobrany kolor, połączony z obrazem, przyciągnie uwagę odbiorców i stworzy pewien ciąg pozytywnych skojarzeń zgodnych z preferencjami odbiorców.

Poniżej wyszczególniono przykłady zastosowania kolorów w praktyce jako komponentu kreującego wygląd komunikatu wizualnego:

1. Czerwony - jest kolorem bardzo intensywnym emocjonalnie, powinien być stosowany, gdy chcemy podkreślić jakąś szczególną okazję, zachęcić

${ }^{16}$ K.J. Rychter, Z. Chmielewski, D. Tworzydło, Tożsamość wizualna: znak, system, wizerunek, Rzeszów 2012, s. 68. 
do działania natychmiastowego, na przykład do udziału w akcji, gdy organizujemy zbiórkę lub wymagamy szczególnej uwagi.

2. Pomarańczowy - łączy energię czerwieni z pogodą koloru żółtego. Lubiany przez ludzi młodych, oznacza fascynację i radość. Możemy użyć tego koloru do promocji akcji przeznaczonej dla młodszych czytelników, których chcemy zaprosić do naszej biblioteki.

3. Żółty - oznacza radość, szczęście, energię i intelekt. Podkreśla bezpieczeństwo, nadaje się do promocji ofert miłego spędzenia wolnego czasu.

4. Zielony - kolor natury, kojarzony z dobrym zdrowiem, harmonią, świeżością. Kolor właściwy dla biblioteki, gdy chcemy zapewnić odbiorców o spokoju, ładzie i ciszy panującej w naszej instytucji.

5. Niebieski - kolor morza i nieba, oznacza stabilizację, także prawdę, mądrość, wiarę, lojalność. Dobry gdy chcemy zaprosić użytkowników do instytucji z długą tradycją, oferującej wiedzę na najwyższym poziomie.

6. Czarny - kojarzony z mocą, elegancją, tajemniczością, ale także ze złem i śmiercią. W kompozycji równoważmy czerń używając bieli, nadaje się jako tło, daje dobry kontrast. Może być kojarzony z obszarami miejskimi, nowoczesnością i luksusem.

Podstawowe cechy dobrego logo to: prostota, rozpoznawalność, ponadczasowość. Zasady jego projektowania można streścić w sposób następujący:

- $\quad$ nie więcej niż trzy kolory;

- $\quad$ nie więcej niż dwa kroje pisma;

- mniej znaczy więcej;

- $\quad$ z bliska i z daleka wygląda tak samo dobrze;

- $\quad$ nie sil się na nadmierną oryginalność, logo ma znaczenie praktyczne;

- $\quad \operatorname{logo}$ ma być ponadczasowe - (mody się zmieniają).

Tożsamość wizualną biblioteki tworzy również jej strona internetowa stanowiąca wizytówkę instytucji na równi z jej rzeczywistą siedzibą. Szablon strony internetowej oraz jej cała zawartość powinna być spójna z polityką wizerunkową firmy. Ponieważ szata graficzna strony pierwsza przyciąga wzrok i zapada w pamięć, a także może zdecydować o dalszym zainteresowaniu odbiorcy, istotne są: jej estetyka, aktualność i przejrzystość. Czytelność i łatwość nawigacji odrywają równie ważną rolę jak zamieszczone na stronie treści.

Odpowiednio dobrana kolorystyka, spójna i konsekwentna identyfikacja wizualna pozwalają odbiorcy na związanie się emocjonalne z przekazywanymi treściami. Tworząc stronę internetową naszej biblioteki powinno się określić grupę docelową, do której strona będzie skierowana, zbadać jej potrzeby i oczekiwania, a także zadbać o to, by działała bez zarzutu na każdym sprzęcie: komputerach stacjonarnych, laptopach, telefonach komórkowych, tabletach, czytnikach. 


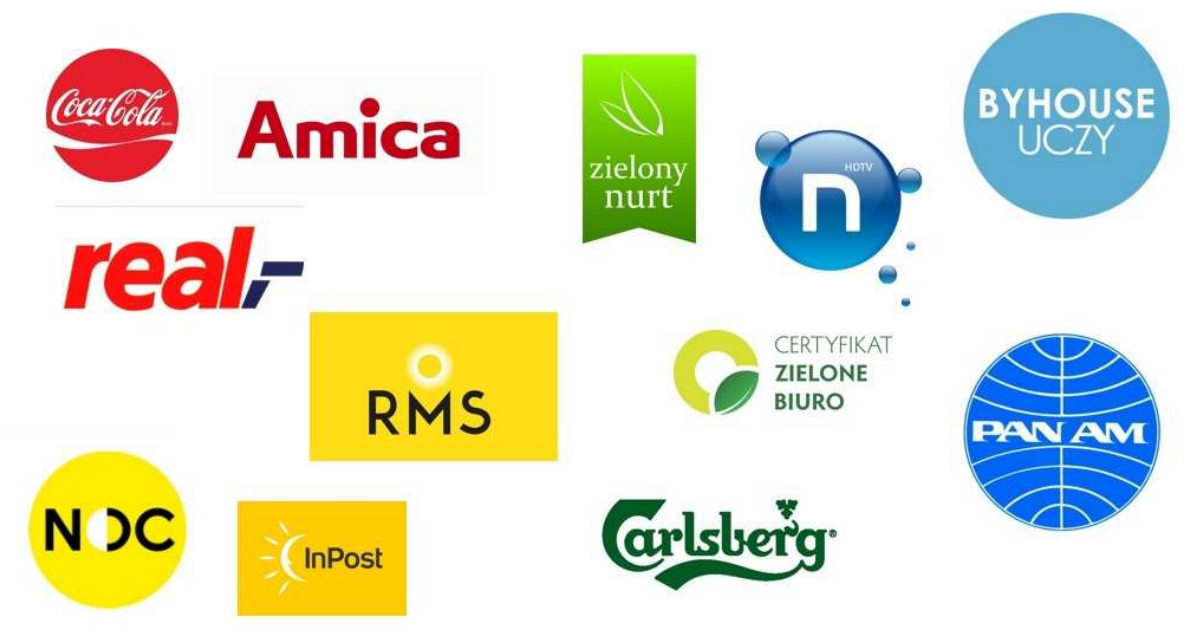

Rys. 10. Przykład zastosowania jednolitej kolorystki w projektowaniu logotypów firmowych: loga firm komercyjnych

Źródło: Coca cola, http://www.coca-cola.pl, [dostęp: 10.10.2017]; Amica, https://www. amica.pl/, [dostęp: 10.10.2017]; Real, https://real.promoceny.pl/, [dostęp: 10.10.2017]; Zielony Nurt, http://zielonynurt.pl, [dostęp: 10.10.2017]; Zielone Biuro, http://www.zielonebiuro.com/, [dostęp: 10.10.2017]; Carlsberg, http://www.carlsberg.pl, [dostęp: 10.10.2017]; NC Plus, http:// ncplus.pl/, [dostęp: 10.10.2017]; Byhouse Architects, http://byhousearchitects.pl/byhouse-uczyniebieskie1/, [dostęp: 10.10.2017]; PanAm, http://www.panam.org/, [dostęp: 10.10.2017]; RMS, https://rms.sds.pl/, [dostęp: 10.10.2017]; InPost, https://inpost.pl/, [dostęp: 10.10.2017]; Noc Bibliotek, https://nocbibliotek.org/, [dostęp: 10.10.2017].

System komunikacji przedsiębiorstwa, system zachowań charakterystyczny dla danej firmy, budowa identyfikacji wizualnej firmy to istotne składniki kompleksowej identyfikacji instytucji tworzące narzędzie do kontaktu z czytelnikiem. System identyfikacji wizualnej może pełnić różnorakie funkcje - od funkcji identyfikacyjnej (wskazanie danej instytucji), poprzez funkcję informacyjną (przekazywanie podstawowych informacji), aż do funkcji wyróżniania spośród konkurencyjnych firm. Jednakże to dzięki komunikacji wizualnej biblioteka nawiązuje dialog ze społecznością akademicką tworząc kod zrozumiały zarówno dla nadawcy, jak i dla odbiorcy. Kanałem informacyjnym w tym przypadku staje się cały system znaków wizualnych biblioteki uczelnianej. Stworzenie Księgi Znaku nie jest obowiązkowe, jednakże bardzo ułatwia funkcjonowanie instytucji, która profesjonalnie podchodzi do kwestii własnej tożsamości. W oparciu o nią łatwiej stosować znak w sposób jednorodny i prawidłowy, a szczegółowa, dobrze obmyślana, opracowana i odpowiednio wdrożona w życie księga identyfikacji wizualnej daje gwarancję wysokiej jakości. 


\section{Bibliografia}

Albin K., Reklama: przekaz, odbiór, interpretacja, Warszawa 2000.

Augustyn R., Kawecka U., System identyfikacji wizualnej biblioteki jako element komunikacji z czytelnikiem, „Biuletyn EBIB” 2011, nr 5, http://www.ebib.pl/?page_ $\mathrm{id}=347$ \#art8, [dostęp:10.10.2017].

Baj M., Logo wybranych bibliotek państwowych uczelni akademickich $w$ Polsce - próba oceny, [w:] Biblioteka jako marka: Materiały z VII Forum Młodych Bibliotekarzy w Łodzi 11-12 września 2012 r., red. J. Stawińska, Warszawa 2013, s. $15-22$.

Bajbak P., Struktura systemu identyfikacji wizualnej firmy, [w:] Produkcja przekazów multimedialnych, red. M. Chrząścik, Warsza wa 2013, s. 105-135.

Bentyn Z., Identyfikacja wizualna przedsiębiorstwa, Poznań 2011.

Benicewicz-Miazga A., Grafika w biznesie: logotypy, wizerunki, papier firmowy: projektowanie elementów tożsamości wizualnej, Gliwice 2005.

Budzyński W., Public relations: zarzadzanie reputacja firmy, Warszawa 1998.

Frutiger A., Człowiek i jego znaki, Kraków 2010.

Jaskowska M., Public relations bibliotek naukowych w Internecie, Kraków 2007.

Jurowski M., Jednolita identyfikacja wizualna, „Biuletyn EBIB” 2004, nr 5, http:// www.ebib.p1/2004/56/jurowski.php, [dostęp: 10.10.2017].

Kaczmarczyk M., Public relations szkót wyższych: model komunikowania się z otoczeniem w demokratycznej przestrzeni publicznej, Sosnowiec 2013.

Klag M., Informacje i emocje - o czytaniu logotypów, [w:] Ikoniczność znaku: stowo - przedmiot - obraz - gest, red. E. Tabakowska, Kraków 2006, s. 69-79.

Kmita A., Identyfikacja firmy: system komunikatów wizualnych, Sosnowiec 2006.

Kołodziejczyk E., E-wizerunek biblioteki - na przykładzie witryn internetowych łódzkich bibliotek szkół wyższych, „Biuletyn EBIB” 2012, nr 3, http://www.ebib.pl/? page_id=858\#art8, [dostęp: 10.10.2017].

Kreft J., Za fasada społeczności: elementy zarządzania nowymi mediami, Kraków 2015.

Kruszewski T., Przestrzenie biblioteki: o symbolicznej, fizycznej i społecznej obecności instytucji, Toruń 2012.

Kwiecień A., Przesłanki i czynniki ksztaltowania reputacji firmy, „Ekonomia” 2003, nr 10, s. 138-153.

Lato A., Ikoniczność we współczesnym, zglobalizowanym świecie - forma komunikacji czy manipulacji?, „Kultura-Historia-Globalizacja” 2008, nr 3, s. 22-31.

Nikodemska-Wołowik A., Górski T., Wołowik M., Nie tylko logotyp: wyróżnienie i przynależność w biznesie, Bydgoszcz-Gdańsk 2004.

Nuckowski J., O komunikacji wizualnej, [w:] Oblicza komunikowania wizualnego, red. R. Polak, Kraków-Rzeszów-Zamość 2011, s. 11-48.

Ogonowska A., Kultura, komunikacja i kompetencja wizualna w kontekście wybranych zagadnień wspótczesnej humanistyki, [w:] Komunikologia: teoria i praktyka komunikacji, red. E. Kulczycki, M. Wendland, Poznań 2012, s. 53-67. 
Rychter K, Chmielewski, Z., Tworzydło, D., Tożsamość wizualna: znak, system wizerunek, Rzeszów 2012.

Schmitt B, Simonson A., Estetyka w marketingu: strategiczne zarzadzanie markami, tożsamościa $i$ wizerunkiem firmy, Kraków 1999.

Scott D., Nowe zasady marketingu i PR, Warszawa 2009.

Vandendorpe Ch., Od papirusu do hipertekstu: esej o przemianach tekstu i lektury, Warszawa 2008.

Wojciechowska M., Fizyczne artefakty kultury organizacyjnej jako element komunikacji marketingowej: na przyktadzie systemu identyfikacji wizualnej, http://docpla yer.pl/16268985-Fizyczne-artefakty-kultury-organizacyjnej-jako-element-komu nikacji-marketingowej-na-przykladzie-systemu-identyfikacji-wizualnej.html, [dostęp: 25.09.2017]. 